\title{
UPAYA PERLINDUNGAN HUKUM TERHADAP PEKERJA PERKEBUNAN KOPI DI KABUPATEN JEMBER
}

\author{
Rosalind Angel Fanggi ${ }^{1}$ \\ Email: rosalind_fanggi@yahoo.com
}

\begin{abstract}
The dominance land use of the region Jember City is for agricultural activities that area of 5099.283 hectares or $51.47 \%$ of the total area of the city. The economic life of the city is more supported by agricultural activities. This condition also occurs in Jember city where good agriculture crop farming and horticulture. The attention to the protection of workers' safety coffee plantations in Jember become essential given that are the basis for improving the quality of the coffee commodity itself. The rise of workplace accidents and lack of attention to workers in the spotlight of its own in the world of the coffee plantation. If workers can work well and healthy then it is not only companies benefiting but the state in its capacity to build the people's welfare have been realized.
\end{abstract}

Keywords: the protection of workers' safety, healty workers, improving the quality

\section{Pendahuluan}

Kabupaten Jember merupakan salah satu kabupaten di Jawa Timur yang memiliki potensi besar di bidang pengolahan hasil pertanian. Bahkan Kabupaten Jember dicanangkan sebagai daerah agrobisnis. Kopi merupakan salah satu hasil komoditi perkebunan yang memiliki nilai ekonomis yang cukup tinggi di antara tanaman perkebunan lainnya dan berperan penting sebagai sumber devisa negara. Kopi tidak hanya berperan penting sebagai sumber devisa melainkan juga merupakan sumber penghasilan bagi tidak kurang dari satu setengah juta jiwa petani kopi di Indonesia ${ }^{2}$. Pada tahun 2009 volume ekspor kopi robusta Indonesia meningkat menjadi 434.430 ton dari tahun sebelumnya 2008 sebanyak 348.187 ton. Kemudian pada tahun 2011 volume ekspor kopi robusta Indonesia menurun menjadi 265.368 ton. Nilai ekspor kopi

\footnotetext{
1 Penulis adalah Dosen Hukum Pidana Fakultas Hukum Universitas Jember

${ }^{2}$ Pudji Rahardjo, (2012), Panduan Budidaya dan Pengolahan Kopi Arabika dan Robusta, Jakarta:

Penebar Swadaya, hlm. 15.
} 
Indonesia berfluktuatif. Fluktuasi nilai ekspor lebih dipengaruhi oleh perubahan harga kopi dibandingkan dengan perubahan volume ekspor (AEKI, 2012). Setiap tahun jumlah ekspor kopi robusta Indonesia mengalami peningkatan ini dibuktikan adanya peningkatan pemesanan biji kopi (green bean) oleh negara lain, tetapi tidak diikuti perluasan lahan budidaya kopi. Peningkatan produksi kopi di Indonesia masih terhambat oleh rendahnya mutu biji kopi yang dihasilkan sehingga mempengaruhi pengembangan produksi akhir kopi. Hal ini disebabkan, karena penanganan pasca panen yang tidak tepat antara lain proses fermentasi, pencucian, sortasi, pengeringan, dan penyangraian. Selain itu, pada proses sortasi yang masih dilakukan secara manual oleh para buruh karena rendahnya penerapan teknologi di Indonesia. Musim panen ini biasanya terjadi mulai bulan Mei/Juni dan berakhir pada bulan Agustus/September Pemanenan buah kopi dilakukan dengan cara memetik buah kopi yang telah masak pada tanaman kopi yang berusia sekitar 2,5-3 tahun. Buah masak ditandai perubahan warna, semulai berwarna hijau menjadi merah seutuhnya. Buah yang berwarna jingga menandakan buah setengah matang. Kopi gelondong yang telah dipanen dibawa ke proses pengolahan selanjutnya. Untuk mendapatkan hasil yang bermutu tinggi, buah kopi harus dipetik dalam keadaan masak penuh. Kopi robusta memerlukan waktu $8-11$ bulan sejak dari kuncup sampai matang. Presentase jumlah buah masak seluruhnya sebesar 95\%, hal ini guna meningkatkan mutu produksi kopi PTP Nusantara. Buah kopi hasil panen ditimbang untuk mengetahui berat awal sebagai analisa mutu.

Semakin meningkatnya perkembangan komoditas kopi maka tenaga kerja yang terserap juga akan semakin banyak, sehingga dengan perkembangan industri yang pesat maka menimbulkan masalah baru mengenai keselamatan dan kesehatan sumber daya manusia. Maraknya kecelakaan kerja dan minimnya perhatian terhadap pekerha menjadi sorotan tersendiri dalam dunia perkebunan kopi ini. Misalnya kecelakaan kerja yang terjadi pada saat bekerja atau pun kondisi kesehatan yang menurun pasca tidak sebagai pekerja yang diakibatkan minimnya sarapa keselamatan kerja pada saat aktif bekerja seperti halnya tidak menggunakan penutup telinga saat bekerja dengan suara mesin yang bising. Sehingga setelah tidak bekerja kecenderungan mengalami gangguan pendengaran menjadi tinggi. Hal ini akhirnya mengurangi kualitas hidup penduduk Indonesia. 
Setiap kali terjadi kecelakaan, korban kecelakaan itulah yang biasanya dipersalahkan. Komentar-komentar bernada mencemooh seperti "Salah sendiri kenapa lalai," atau "hal ini tak akan terjadi kalau saja dia lebih berhati-hati" merupakan komentar yang sering kita dengar bila terjadi kecelakaan. Pihak manajemen seringkali mengambil sikap menyalahkan korban kecelakaan karena mereka tidak mau dimintai pertanggungjawaban dan karena mereka tidak mau mengeluarkan biaya untuk melakukan perbaikan yang perlu untuk mencegah kecelakaan itu terulang kembali. Sayangnya, banyak pekerja mau menerima begitu saja pendapat yang dilontarkan manajemen karena mereka beranggapan bahwa bahaya di tempat kerja merupakan hal yang lumrah. Padahal penyebab sesungguhnya kecelakaan kerja adalah kondisi bahaya yang ada. "Mengendalikan bahaya langsung dari sumbernya" adalah cara terbaik untuk menjaga keselamatan dan kesehatan kerja. Artinya, perusahaan tidak boleh beranggapan bahwa karyawannya dapat diandalkan untuk selalu berhati-hati, tidak lalai atau tidak ceroboh karena tidak ada manusia sempurna yang dapat diharapkan untuk tidak pernah lengah. Ini berarti kondisi-kondisi yang berpotensi menimbulkan bahaya harus disingkirkan atau dikendalikan untuk memastikan bahwa kecelakaan tidak dapat terjadi. Tentu saja, pekerja perlu sekali dilatih dan dididik agar mereka sadar akan bahaya yang dapat menimpa mereka pada saat bekerja. Tetapi hal ini tidak lalu berarti bahwa mereka sudah layak dan sepantasnya untuk dimintai pertanggungjawaban jika terjadi kecelakaan

Perhatian terhadap perlindungan terhadap keselamatan pekerja perkebunan kopi di Kabupaten Jember menjadi hal yang penting mengingat kualitas pekerja menjadi komponen yang dasar dalam peningkatan mutu dalam komoditas kopi itu sendiri. Jika pekerja dapat bekerja dengan baik dan sehat maka sebenarnya bukan saja perusahaan yang diuntungkan tetapi negara dalam kapasitasnya membangun kesejahteraan rakyat telah terwujud. Mengacu latar belakang yang diuraikan di atas berikut ini dapat dianalisis beberapa permasalahan yaitu: 1) Hal-hal apa sajakah yang menjadi faktor pendorong kurangnya perhatian perlindungan terhadap keselamatan pekerja perkebunan kopi di Kabupaten Jember. 2) Bagaimana upaya perlindungan hukum terhadap keselamatan pekerja perkebunan kopi di Kabupaten Jember. 


\section{Metode Penelitian}

Data yang dibutuhkan dalam penelitian ini adalah data primer dan data sekunder. Data primer lebih diutamakan dibandingkan dengan data sekunder. Data primer diperoleh melalui sumber primer, yaitu data yang diperoleh secara langsung dari informan di lapangan. Data sekunder berupa data yang dikumpulkan melalui studi kepustakaan.

Informan yang dibutuhkan dalam penelitian ini adalah informan pangkal dan informan utama. Informan pangkal adalah para pekerja perkebunan. Teknik pengumpulan data dalam penelitian ini meliputi: 1) Wawancara. Teknik wawancara yang dilakukan adalah wawancara tak terarah (nondirective interview). Tujuan dari pemilihan tipe wawancara ini adalah supaya mampu menggali lebih dalam informasiinformasi dari informan tentang segala sesuatu yang ingin dikemukakannya. Dengan cara itu peneliti akan memperoleh gambaran yang lebih luas tentang fokus permasalahan; oleh karena informan bebas meninjau berbagai aspek menurut pendirian dan pikirannya sendiri, dan dengan demikian akan dapat memperkaya pandangan peneliti. 2) Teknik angket (kuesioner). Peneliti lakukan dengan jalan menyebarkan 100 kuesioner (responden) pada sejumlah komponen yaitu pemimpin perusahaan dan para pekerja. 3) Kepustakaan. Teknik kepustakaan digunakan untuk menggali data-data yang bersifat sebagai pelengkap dan pembanding terhadap data yang diperoleh dengan teknik wawancara atau teknik angket (kuesioner).

Data yang telah terkumpul selanjutnya dianalisis secara diskriptif. Data yang diperoleh dari bahan-bahan hukum (kepustakaan atau peraturan perundang-undangan) dianalisis secara yuridis-normatif dan yuridis-sosiologis. Teknik analisis dilakukan dengan metode interpretasi hukum.

\section{Pembahasan}

\section{Hal-Hal Yang Menjadi Faktor Pendorong Kurangnya Perhatian Perlindungan Terhadap Keselamatan Pekerja Perkebunan Kopi Di Kabupaten Jember}

Situasi dan kondisi perlindungan terhadap keselamatan pekerja perkebunan kopi di Kabupaten Jember pada saat ini dari asumsi dasar bahwa terdapat kurangnya perhatian terhadap keselamatan pekerja di perkebunan kopi di Kabupaten Jember akan diuraikan 
lebih lanjut hal-hal apasajakah yang menjadi faktor pendorong kurang diperhatikannya keselamatan kerja pekerja perkebunan kopi di Kabupaten Jember.

Keselamatan kerja termasuk dalam perlindungan teknis, yaitu perlindungan terhadap pekerja/buruh agar selamat dari bahaya yang dapat ditimbulkan oleh alat kerja atau bahan yang dikerjakan. Keselamatan kerja tidak hanya memberikan perlindungan kepada pekerja/buruh, tetapi juga kepada pengusaha dan pemerintah :

a. Bagi pekerja/buruh, adanya jaminan perlindungan keselamatan kerja akan menimbulkan suasana kerja yang tenteram sehingga pekerja/buruh akan dapat memusatkan perhatiannya pada pekerjaannya semaksimal mungkin tanpa khawatir sewaktu-waktu akan tertimpa kecelakaan kerja.

b. Bagi pengusaha, adanya pengaturan keselamatan kerja di perusahaannya akan dpat mengurangi terjadinya kecelakaan yang dapat mengakibatkan pengusaha harus memberikan jaminan sosial.

c. Bagi pemerintah (dan masyarakat), dengan adanya dan ditaatinya peraturan keselamatan kerja, maka apa yang direncanakan pemerintah untuk menyejahterakan masyarakat akan tercapai dengan meningkatnya produksi perusahaan baik kualitas maupun kuantitasnya.

Pemerintah telah melakukan upaya pembinaan norma di bidang ketenagakerjaan Untuk mewujudkan perlindungan keselamatan kerja. Dalam pengertian pembinaan norma ini sudah mencakup pengertian pembentukan, penerapan dan pengawasan norma itu sendiri ${ }^{4}$.

Ditinjau dari segi keilmuan, keselamatan dan kesehatan kerja diartikan sebagai ilmu pengetahuan dan penerapannya dalam usaha mencegah kemungkinan terjadinya kecelakaan dan penyakit akibat kerja. Keselamatan dan kesehatan kerja harus diterapkan dan dilaksanakan di setiap tempat kerja (perusahaan).

Disamping ada sebabnya maka suatu kejadian juga akan membawa akibat. Akibat dari kecelakaan industri ini dapat dikelompokkan menjadi dua, yaitu : pertama

\footnotetext{
${ }^{3}$ Zaeni Asyhadie, (2007), Hukum Kerja Hukum Ketenagakerjaan Bidang Hubungan Kerja,Jakarta : Raja Grafindo, Hlm.94-95.

${ }^{4}$ Lalu Husni, (2004), Hukum Ketenagakerjaan Indonesia, Jakarta : Rajawali press, Hlm.138.
} 
kerugian yang bersifat ekonomis, antara lain kerusakan / kehancuran mesin, peralatan, bahan dan bangunan. Biaya pengobatan dan perawatan korban. Tunjangan kecelakaan. Hilangnya waktu kerja. Menurunnya jumlah maupun mutu produksi. Kedua kerugian yang bersifat non ekonomis. Pada umumnya berupa penderitaan manusia yaitu tenaga kerja yang bersangkutan, baik itu merupakan kematian, luka/cedara berat maupun ringan. ${ }^{5}$

Menurut International LabourOrganization (ILO) ada beberapa cara atau langkah yang perlu diambil untuk menanggulangi kecelakaan yang terjadi di tempat kerja, yaitu melalui : ${ }^{6}$

a. Peraturan perundang-undangan.

- Adanya ketentuan dan syarat-syarat K3 yang selalu mengikuti perkembangan ilmu pengetahuan, teknik dan teknologi (up to date).

- Penerapan semua ketentuan dan persyaratan keselamatan dan kesehatan kerja sesuai dengan peraturan perundangan yang berlaku sejak tahap rekayasa.

- Penyelenggaraan pengawasan dan pemantauan pelaksanaan K3 melalui pemeriksaan-pemeriksaan langsung di tempat kerja.

b. Standarisasi. Merupakan suatu ukuran terhadap besaran-besaran nilai. Standard K3 yang maju akan menentukan tingkat kemajuan K3, karena pada dasarnya baik buruknya K3 di tempat kerja diketahui melalui pemenuhan standard K3.

c. Inspeksi. Kegiatan-kegiatan yang dilakukan dalam rangka pemeriksaan dan pengujian terhadap tempat kerja, mesin, pesawat, alat dan instalasi, sejauh mana masalah-masalah ini masih memenuhi ketentuan dan persyaratan K3.

d. Riset, meliputi :

- Riset teknik, penelitian terhadap benda dan karakteristik bahan-bahan berbahaya. Mempelajari pengaman mesin, pengujian alat pelindung diri, penyelidikan tentang desain yang cocok untuk instalasi industri.

- Riset medis, meliputi hal-hal khusus yang berkaitan dengan penyakit akibat

\footnotetext{
${ }^{5}$ Lalu Husni, Op.Cit, hlm. 143

${ }^{6} \mathrm{http} / / / \mathrm{www}$. ilo.org/wcmsp5/groups/public/---asia/---ro-bangkok/---ilojakarta/documents/publication/wcms 237650.pdf dikses 7 Juni 2015
} 
kerja dan akibat medis terhadap manusia dari berbagai kecelakaan kerja.

- Riset psikologis, penelitian terhadap pola-pola pdikologis yang dapat menjurus kearah kecelakaan kerja.

e. Pendidikan. Pemberian pengajaran dan pendidikan cara pencegahan kecelakaan yang terjadi melalui pengamatan terhadap jumlah, jenis orangnya (korban), jenis kecelakaan, factor penyebab, sehingga dapat ditentukan pola pencegahan kecelakaan yang serupa.

f. Training (latihan). Pemberian instruksi atau petunjuk-petunjuk melalui praktek kepada para pekerja mengenai cara kerja yang aman.

g. Persuasi. Menanamkan kesadaran akan pentingnya keselamatan dan kesehatan kerja dalam upaya untuk mencegah terjadinya kecelakaan, sehingga semua ketentuan keselamatan dan kesehatan kerja dapat diikuti oleh semua tenaga kerja.

h. Asuransi. Upaya pemberian insentif dalam bentuk reduksi terhadap premi asuransi kepada perusahaan yang melakukan usaha-usaha keselamatan dan kesehatan kerja atau yang berhasil menurunkan tingkat kecelakaan di perusahaannya.

i. Penerapan K3 di tempat kerja. Langkah-langkah tersebut haris dapat diaplikasikan di tempat kerja dalam upaya memenuhi syarat-syarat $\mathrm{K} 3$ di tempat kerja.

Kesehatan kerja adalah bagian dari ilmu kesehatan yang bertujuan agar tenaga kerja memperoleh keadaan kesehatan yang sempurna baik fisik, mental maupun social sehingga memungkinkan dapat bekerja secara optimal.Berdasarkan hasil penelitian dapat diperoleh informasi bahwa para pekerja rata-rata telah bekerja selama lebih dari lima tahun bahkan ada yang telah bekerja di atas sepuluh tahun. Secara keseluruhan para pekerja ini merasakan nyaman bekerja di PT J.A. Wattie Perkebunan Durjo Jember. Hal ini tentunya dapat dilihat dari lamanya mereka telah bekerja. Pelaksanaan kegiatan berlangsung selama \pm 7 jam, terhitung mulai pukul 06.00 WIB sampai dengan 13.00 WIB dengan waktu istirahat selama 30 menit pada pukul 09.00 WIB. Pelaksanaan kegiatan sortasi jam, terhitung mulai pukul 06.00 WIB sampai dengan 13.00 WIB dengan waktu istirahat selama 30 menit. Banyaknya pekerja yang cepat mengalami kelelahan dikhawatirkan juga berakibat pada penurunan produksi di PT. J. 
A. Wattie Perkebunan Durjo Jember. Persentase keluhan umum pekerja yang terdapat di PT. J. A. Wattie Perkebunan Durjo menyajikan tentang keluhan umum pekerja. Hampir sebagian besar responden merasa nyaman dengan kondisi lingkungan kerja. Hanya saja sebagian besar setelah melakukan kerja di pabrik banyak yang mengeluhkan sakit di pergelangan tangan, leher, pantat, pinggang dan punggung juga rasa pegal linu di betis kaki. Proses pengolahan di PT. J. A. Wattie Durjo Jember masih belum dilakukan analisis aspek ergonomisnya, akibatnya terdapat beberapa pekerja yang masih mengalami keluhan atau rasa tidak nyaman di lingkungan kerja khususnya bagian sortasi akhir kopi robusta. Hal tersebut dapat diketahui dari desain meja dan kursi yang terdapat di PT. J. A. Wattie Perkebunan Durjo Jember. Desain meja dan kursi untuk saat ini bisa dikatakan masih belum ergonomis sehingga menyebabkan ketidaknyamanan terhadap pekerja dalam melakukan pekerjaannya. Oleh karena itu maka perlu dilakukan penelitian tentang aspek ergonomis guna untuk mengevaluasi aspek ergonomis pekerja bagian sortasi di PT. J. A. Wattie Perkebunan Durjo Jember ${ }^{7}$.

Hasil penelitian menunjukan bahwa kondisi lingkungan (suhu, kelembaban dan kebisingan suara) masih belum optimum. Nilai optimum suhu, dan kelembaban ruangan untuk orang bekerja berturut-turut yaitu $25^{\circ}-27^{\circ} \mathrm{C}, 70 \%-80 \%$ dan $85 \mathrm{~dB}$. Suhu dan kelembaban di ruang sortasi PT. J. A. Wattie Perkebunan Durjo Jember pada pukul 06.00 WIB, 09.00 WIB dan 12.00 WIB berturut-turut adalah $19,8^{\circ} \mathrm{C}$ dan $86 \%$; $28,7^{\circ} \mathrm{C}$ dan $72,78 \% ; 30^{\circ} \mathrm{C}$ dan $68,5 \%$, sedangkan tingkat kebisingan suara dibeberapa tahapan produksi yaitu pada proses pulping $85 \mathrm{~dB}$, washing $94 \mathrm{~dB}$, bordes $88 \mathrm{~dB}$ dan hulling \& pengayakan adalah 99 dB. Hasil perhitungan untuk desain meja memilki panjang yaitu $195 \mathrm{~cm}$, lebar $70 \mathrm{~cm}$ dan tinggi $80 \mathrm{~cm}$, sedangkan ukuran kursi yang diperoleh yaitu panjang $120 \mathrm{~cm}$, tinggi (tanpa sandaran) $46 \mathrm{~cm}$, panjang sandaran $100 \mathrm{~cm}$ dan lebar sandaran $54 \mathrm{~cm}$. Desain meja dan kursi yang sebelumnya mengalami perubahan ukuran antara lain tinggi meja, tinggi kursi, lebar meja dan lebar kursi. Adanya suatu desain yang ergonomis diharapkan mampu

\footnotetext{
${ }^{7}$ Andrew Setiawan. Dkk, (2012), Analisis Aspek Ergonomi Pekerja Bagian Sortasi Akhir Pada Pengolahan Kopi Robusta Secara Semi Basah (Studi Kasus PT. J. A. Wattie Perkebunan Durjo Jember) dimuat di Jurnal Agrointek Volume 6 Tahun 2012. Hlm. 56.
} 
meningkatkan produktifitas dalam melakukan kegiatan sortasi tanpa menimbulkan suatu kelelahan tubuh yang terlalu cepat. ${ }^{8}$ Hal ini antara lain disebabkan oleh kurang nyamannya sarana kerja (meja dan kursi). Sebab untuk kopi ruangan pemeriksaan kualitasnya harus disesuaikan dengan kelembaban tertentu sehingga hal ini juga mempengaruhi para pekerjanya. Keselamatan kerja termasuk dalam perlindungan teknis, yaitu perlindungan terhadap pekerja/buruh agar selamat dari bahaya yang dapat ditimbulkan oleh alat kerja atau bahan yang dikerjakan. Keselamatan kerja tidak hanya memberikan perlindungan kepada pekerja/buruh, tetapi juga kepada pengusaha dan pemerintah. Keselamatan dan kesehatan kerja harus diterapkan dan dilaksanakan di setiap tempat kerja (perusahaan). Tempat kerja adalah setiap tempat yang di dalamnya terdapat 3 (tiga) unsur, yaitu adanya suatu usaha, baik itu usaha yang bersifat ekonomis maupun sosial, adanya sumber bahaya dan adanya tenaga kerja yang bekerja di dalamnya, baik secara terus menerus maupun hanya sewaktuwaktu.

\section{Upaya Perlindungan Hukum Terhadap Keselamatan Pekerja Perkebunan Kopi Di}

\section{Kabupaten Jember}

Pemikiran atau konsep yang menguntungkan bagi pekerja dan perusahaan terkait upaya perlindungan hukum bagi pekerja di perkebunan kopi di Kabupaten Jember. Harapannya dengan adanya konsep pemikiran win-win solution dapat dijadikan semangat untuk meningkatkan produktifitas pekerja serta memantapkan posisi perusahaan dalam upaya mewujudkan pembangunan Indonesia seutuhnya. Hal ini tidak lepas pula dari sifat komoditas kopi yang telah menjadi komoditas ekspor Indonesia. Terkait upaya perlindungan hukum terhadap keselamatan pekerja perkebunan kopi di Kabupaten Jember menurut peneliti apa yang dilakukan pihak perusahan sudah cukup memberi perlindungan hukum. Undang-Undang Nomor 2 Tahun 2004 tetang Penyelesaian Perselisiah Hubungtan Industrial, mengartikan pekerja/buruh, adalah setiap orang yang bekerja dengan menerima upah atau imbalan dalam bentuk lain. Pekerja/ buruh lebih dikenal dengan istilah buruh (labor). Sehubungan dengan istilah buruh ini soepomo mengartikannya adalah: "Ia atau mereka yang bekerja dalam

\footnotetext{
${ }^{8}$ ibid
} 
hubungan kerja, yaitu ada di bawah perintah orang lain dengan menerima upah". Pekerja/ buruh sering pula disebut karyawan atau pegawai, sebetulnya adalah juga pengertian yang sama dengan pekerja/buruh. Penggunaan istilah tersebut cenderung dipengaruhi oleh adanya klasifikasi, bahwa seolah-olah persoalan istilah ini melibatkan status dan diskriminasi. Sehingga kalau pengertian karyawan atau pegawai berstatus terhormat, sedang pengertian buruh menunjuk ke pekerjaan kasar. Keselamatan dan kesehatan kerja berarti bebas dari kecelakaan, cedera atau sakit yang diakibatkan oleh tindakan yang gegabah dan ceroboh sewaktu bekerja dan oleh kondisi kerja yang tidak memadai. Untuk mencegah terjadinya hal-hal yang tidak diinginkan tersebut, kita harus menghapus praktek-praktek dan kondisi kerja yang tidak mengindahkan prinsip-prinsip keselamatan dan keamanan kerja. Peran serikat pekerja/serikat buruh harus diawali dari titik di mana terjadi kerusakan, baik di tempat kerja atau di sekitar tempat kerja. Serikat pekerja/serikat buruh harus mampu mengidentifikasi masalah dan hal-hal yang mengancam kesehatan dan keselamatan kerja, serta mempunyai informasi dan pengaruh yang diperlukan untuk menekan pihak manajemen agar segera melakukan perbaikanperbaikan. Setiap kali terjadi kecelakaan atau ada pekerja yang sakit, sering kali justru pekerja yang menjadi korban kecelakaan atau pekerja yang terkena penyakit itulah yang dipersalahkan. Manajemen sering kali berkata bahwa kecerobohanlah yang merupakan penyebab utama terjadinya cedera. Serikat pekerja harus berani menolak analisa seperti ini karena analisa seperti ini merupakan usaha manajemen untuk cuci tangan terhadap masalah yang ada dan membuat pekerja menjadi pihak yang bertanggung jawab terhadap masalah keselamatan atau kesehatan kerja yang terjadi.

Perlindungan hukum dibutuhkannya suatu tempat atau wadah dalam pelaksanaannya yang sering disebut dengan sarana perlindungan hukum. 1) Sarana Perlindungan Hukum Preventif. Pada perlindungan hukum preventif ini, subyek hukum diberikan kesempatan untuk mengajukan keberatan atau pendapatnya sebelum suatu keputusan pemerintah mendapat bentuk yang definitif. Tujuannya adalah mencegah terjadinya sengketa. Perlindungan hukum preventif sangat besar artinya bagi tindak pemerintahan yang didasarkan pada kebebasan bertindak karena dengan adanya perlindungan hukum yang preventif pemerintah terdorong untuk bersifat hati-hati dalam mengambil keputusan yang didasarkan pada diskresi. Di indonesia belum ada 
pengaturan khusus mengenai perlindungan hukum preventif. 2) Sarana Perlindungan Hukum Represif. Perlindungan hukum yang represif bertujuan untuk menyelesaikan sengketa. Penanganan perlindungan hukum oleh Pengadilan Umum dan Peradilan Administrasi di Indonesia termasuk kategori perlindungan hukum ini. Prinsip perlindungan hukum terhadap tindakan pemerintah bertumpu dan bersumber dari konsep tentang pengakuan dan perlindungan terhadap hak-hak asasi manusia karena menurut sejarah dari barat, lahirnya konsep-konsep tentang pengakuan dan perlindungan terhadap hak-hak asasi manusia diarahkan kepada pembatasanpembatasan dan peletakan kewajiban masyarakat dan pemerintah.

Prinsip kedua yang mendasari perlindungan hukum terhadap tindak pemerintahan adalah prinsip negara hukum. Dikaitkan dengan pengakuan dan perlindungan terhadap hak-hak asasi manusia, pengakuan dan perlindungan terhadap hak-hak asasi manusia mendapat tempat utama dan dapat dikaitkan dengan tujuan dari negara hukum 9 .

Pengertian Perlindungan adalah tempat berlindung, hal (perbuatan dan sebagainya) memperlindungi. Perlindungan yang tertuang dalam Peraturan Pemerintah No.2 Tahun 2002 tentang tata cara perlindungan terhadap korban dan saksi dalam pelanggaran hak asasi Manusia yang Berat adalah suatu bentuk pelayanan yang wajib dilaksanakan oleh aparat penegak hukum atau aparat keamanan untuk memberikan rasa aman baik fisik maupun mental, kepada korban dan saksi, dari ancaman, gangguan, teror, dan kekerasan dari pihak manapun, yang diberikan pada tahap penyelidikan, penyidikan, penuntutan, dan atau pemeriksaan di sidang pengadilan. Pasal 1 angka 4 Undang-undang No. 39 Tahun 2004 tentang Penempatan dan Perlindungan Tenaga Kerja Indonesia di Luar Negeri menyebutkan bahwa Perlindungan TKI yaitu segala upaya untuk melindungi kepentingan calon Tenaga Kerja Indonesia dalam mewujudkan terjaminnya pemenuhan hak-haknya sesuai dengan peraturan perundang-undangan, baik sebelum, selama, maupun sesudah bekerja. Ruang lingkup keselamatan kerja adalah meliputi setiap ruangan atau lapangan, tertutup atau terbuka, bergerak atau tetap di mana tenaga kerja bekerja, atau yang sering dimasuki tenaga kerja untuk keperluan

\footnotetext{
${ }^{9}$ http://tesishukum.com/pengertian-perlindungan-hukum-menurut-para-ahli/ diakses 7 Juni 2015
} 
suatu usaha dan di mana terdapat dumber atau sumber-sumber bahaya. Dikaitkan dengan pengakuan dan perlindungan terhadap hak-hak asasi manusia, pengakuan dan perlindungan terhadap hak-hak asasi manusia mendapat tempat utama dan dapat dikaitkan dengan tujuan dari negara hukum. Dalam hal upaya yang dapat dilakukan untuk keselamatan pekerja perkebunan kopi di Kabupaten Jember antara lain dengan mengganti sarana kerja sehingga sarana kerja berupa meja dan kursi dapat membuat para pekerja tidak mengalami kelelahan sehingga membuat nyaman dalam bekerja sehingga dapat pula meningkatkan produktitivas. Kemudian juga penggunaan masker dan juga perlu diperhatikan suhu dalam ruang kerja. Hal-hal demikian sangat tepat dilakukan dalam upaya perlindungan keselamatan kerja bagi pekerja perkebunan kopi di Jember dalam lingkup perlindungan hukum secara preventif.

\section{Kesimpulan}

Hal-hal yang menjadi faktor pendorong kurangnya perlindungan terhadap keselamatan pekerja perkebunan kopi di Kabupaten Jember antara lain karena masih belum diupayakan secara maksimal terkait dengan keselamatan dan kenyamanan kerja. Hal ini terlihat banyaknya pekerja yang cepat mengalami kelelahan dikhawatirkan juga berakibat pada penurunan produksi di PT. J. A. Wattie Perkebunan Durjo Jember. Sebagian besar setelah melakukan kerja di pabrik banyak yang mengeluhkan sakit di pergelangan tangan, leher, pantat, pinggang dan punggung juga rasa pegal linu di betis kaki. Hal ini antara lain disebabkan oleh kurang nyamannya sarana kerja (meja dan kursi). Selain itu juga karena kurang nyamannya ruangan tempat pekerja ini melakukan rutinitasnya. Sebab untuk kopi ruangan pemeriksaan kualitasnya harus disesuaikan dengan kelembaban tertentu sehingga hal ini juga mempengaruhi para pekerjanya. Keselamatan kerja termasuk dalam perlindungan teknis, yaitu perlindungan terhadap pekerja/buruh agar selamat dari bahaya yang dapat ditimbulkan oleh alat kerja atau bahan yang dikerjakan. Keselamatan kerja tidak hanya memberikan perlindungan kepada pekerja/buruh, tetapi juga kepada pengusaha dan pemerintah.

Upaya perlindungan hukum terhadap keselamatan pekerja perkebunan kopi di Kabupaten Jember. Sarana perlindungan hukum dibagi menjadi dua macam yang dapat dipahami, sebagai berikut: 
a. Sarana Perlindungan Hukum Preventif yang dapat dilakukan melalui pengaturan keselamatan kerja dalam produk undang-undang.

b. Sarana Perlindungan Hukum Represif yang dapat dilakukan dengan melengkapi sarana keselamatan kerja sehingga tercipta kenyamanan dalam bekerja

\section{Saran}

Dalam beberapa hal apa yang dilakukan pihak perkebunan kopi dalam memperhatikan keselamatan pekerjanya sudah kondusif. Hanya saja dalam hal yang lain masih perlu ditingkatkan seperti upaya yang dapat dilakukan untuk keselamatan pekerja perkebunan kopi di Kabupaten Jember antara lain dengan mengganti sarana kerja sehingga sarana kerja berupa meja dan kursi dapat membuat para pekerja tidak mengalami kelelahan sehingga membuat nyaman dalam bekerja sehingga dapat pula meningkatkan produktitivas. Kemudian juga penggunaan masker dan juga perlu diperhatikan suhu dalam ruang kerja. Hal-hal demikian sangat tepat dilakukan dalam upaya perlindungan keselamatan kerja bagi pekerja perkebunan kopi di Jember dalam lingkup perlindungan hukum secara preventif.

\section{DAFTAR PUSTAKA}

Asyhadie, Zaeni, (2007), Hukum Kerja Hukum Ketenagakerjaan Bidang Hubungan Kerja,Jakarta : Raja Grafindo.

Husni, Lalu, (2004), Hukum Ketenagakerjaan Indonesia, Jakarta : Rajawali press.

Rahardjo, Pudji, (2012), Panduan Budidaya dan Pengolahan Kopi Arabika dan Robusta, Jakarta: Penebar Swadaya.

\section{$\underline{\text { Artikel dan Jurnal }}$}

Setiawan, Andrew. Dkk, (2012), Analisis Aspek Ergonomi Pekerja Bagian Sortasi Akhir Pada Pengolahan Kopi Robusta Secara Semi Basah (Studi Kasus PT. J. A. Wattie Perkebunan Durjo Jember) dimuat di Jurnal Agrointek Volume 6 Tahun 2012.

\section{Peraturan Perundang-undangan}

Undang-undang Nomor 13 Tahun 2003 tentang ketenagakerjaan 
Undang-undang Nomor 39 Tahun 2004 tentang Penempatan dan Perlindungan Tenaga Kerja Indonesia di Luar Negeri

Peraturan Pemerintah Nomor 2 Tahun 2002 Tentang Tatacara Perlindungan Korban dan Saksi Dalam Pelanggaran Hak Asasi Manusia Yang Berat

Peraturan Menteri Perburuhan (PMP) RI Nomor 7 Tahun 1964 tentang Syarat Kesehatan, Kebersihan, dan Penerangan dalam Tempat Kerja.

$\underline{\text { Website }}$

http://www.ilo.org/wcmsp5/groups/public/---asia/---ro-bangkok/---ilojakarta/documents/publication/wcms_237650.pdf

http://tesishukum.com/pengertian-perlindungan-hukum-menurut-para-ahli/ 